\title{
Hedge Lane Design Ideas of Xin Zhou City Shan Xi province to Bao De High Way G3 Section
}

\author{
Tang Huazhong \\ Hina Merchants Chongqing Communications Technology Research \& Design Institute Co., LTD, \\ 400067,Chongqing, China
}

Key words: highway, continuous long steep downhill, safe lane, design safety

Abstract: This paper focuses on the design process of the choice of design based on the hedge lane design ideas of Xin Zhou city Shan Xi province to Bao De high way G3 section. Through the analysis of the position, length, and the selection of the packing of the slope, the reference is provided for the establishment of the safe lane of the similar terrain mountain highway in the future.

\section{Introduction}

Currently, with the rapid development of Chinese economy, more and more mountainous expressway will appear. Due to limited terrain and other conditions, continuous long steep Longitudinal sections almost inevitable. Because of complexity with mountainous topography, terrain, geological conditions and other natural conditions, at the mountain highway, there are objective factors which are not conducive to traffic safety, such as large longitudinal slope, long continuous slope length, and so on. For mountain highway, national highway and provincial, the traffic is heavy, especially large proportion of the major vehicles, vehicle brake system failure has become a major factor in traffic accidents. Emergency lane as a measure to improve traffic safety, has been greatly used in many countries. Currently domestic hedge lane applications still in the exploratory stage, comprehensive and systematic research need to accumulate more experience.

\section{Project overview}

Xinzhou highway to Baode is the third (Wutai changchengling to Baode) part of the book "Shanxi Province Highway Network Planning". It is an important strategic channel in the central and northern Shanxi Province, which west to Shanxi, Gansu, Ningxia, east to Beijing, Tianjing, Hebei. The route starting point east of the proposed highway Xinfu, and communicate with the Dayun expressway, via Xinzhou City, Jingle, Ningwu County, Kelan, Baode County five counties, end of the route across the Yellow River, connect with Shenmu to Fugu highway in Shanxi Province. Route length of about $189.342 \mathrm{~km}$. The whole uses two-way four lane expressway standard construction. The design speed is $80 \mathrm{~km} / \mathrm{h}$, roadbed width using $24.5 \mathrm{~m}$.

G3 sections of the route is located in mountainous areas of northwestern Shanxi Province. it is across the Lvliang mountains north of Luya Mountain and Shanxi Loess Plateau, multi wiring along the riverside. The overall topography of the project area is east high and west low. The highest point is located on the route starting point which near the Shangquan village, elevation $1763.00 \mathrm{~m}$. The lowest point is located on Majiahe River near the end of the line, elevation $1295.00 \mathrm{~m}$. The relative elevation is $468.00 \mathrm{~m}$. In addition to the Dongchuan River, LAN Yi River, Beichuan River and mountain valley terrain is relatively flat open, the remaining sections of the terrain is more complex. There are four types of landform units from the east to the west of the road, followed by loess covering low mountain area, mountain valley area, loess hilly area, Tectonic erosion bedrock in low mountain area.

\section{Design route}

\subsection{Hedge Lane location selection}

In continuous long steep downhill, when the proportion of large and medium duty trucks is higher 
in traffic, it is advisable to set up the first place to be a safe escape lane for out of control vehicle after the length of the continuous downhill is greater than the length of the prescribed route, and according to the provisions of the route to increase the length of the hedge Lane.

The longitudinal slope of G3 section is analyzed in detail, the setting of hedge lanes is as follows:

\begin{tabular}{|c|c|c|c|c|c|c|}
\hline ordinal & \multicolumn{2}{|c|}{ Paragraph } & Od pile No & $\begin{array}{l}\text { Length } \\
(\mathrm{km})\end{array}$ & $\begin{array}{r}\text { Slope } \\
(\%)\end{array}$ & Remarks \\
\hline \multirow{3}{*}{1} & \multicolumn{2}{|c|}{$\begin{array}{l}\text { G2 Luyashan tunnel to } \\
\text { Huangdaochuan }\end{array}$} & $\begin{array}{l}\mathrm{K} 88+800 \sim \\
\mathrm{K} 100+830\end{array}$ & \multirow{2}{*}{$\begin{array}{l}13.3 \\
7.5\end{array}$} & \multirow{2}{*}{$\frac{-2.4}{-2.5}$} & \multirow{2}{*}{\begin{tabular}{|l|}
$\begin{array}{l}\text { Downhill } \\
\text { slope }\end{array}$ \\
Need set
\end{tabular}} \\
\hline & \multirow{2}{*}{ Inside } & \begin{tabular}{|lll} 
Luyashan tunnel to \\
K95+100
\end{tabular} & $\begin{array}{l}\mathrm{K} 88+800 \\
\mathrm{~K} 95+050\end{array}$ & & & \\
\hline & & K95+100 Huangdaochuan & $\begin{array}{l}\text { K95+050 } \\
\text { K100+830 }\end{array}$ & 5.8 & -2.3 & Not set \\
\hline 2 & \multicolumn{2}{|r|}{$\begin{array}{l}\text { Huangdaochuan to } \\
\text { Kelan County }\end{array}$} & $\begin{array}{l}\text { K100+830 } \\
\text { K114+600 }\end{array}$ & 13.8 & -1.00 & Not set \\
\hline 3 & \multicolumn{2}{|c|}{ Kelan County to Ganqinshan } & $\begin{array}{l}\mathrm{K} 114+600 \\
\mathrm{~K} 140+380 \\
\end{array}$ & 26.1 & 0.82 & Not set \\
\hline \multirow{3}{*}{4} & \multicolumn{2}{|c|}{ Ganqinshan to $\mathrm{G} 3$ end point } & $\begin{array}{l}\text { K140+380 } \\
\text { K151+085 } \\
\end{array}$ & 10.7 & -2.43 & Not set \\
\hline & \multirow{2}{*}{ Inside } & $\begin{array}{l}\text { Ganqinshan to } \\
\mathrm{K} 147+880\end{array}$ & $\begin{array}{l}\mathrm{K} 140+380 \\
\mathrm{~K} 147+880\end{array}$ & 7.5 & -2.57 & Need set \\
\hline & & $\mathrm{K} 147+880$ to $\mathrm{G} 3$ end point & $\begin{array}{l}\mathrm{K} 147+880 \sim \mathrm{G} \\
\text { end point }\end{array}$ & 3.2 & -2.1 & Not set \\
\hline
\end{tabular}

From the table can be seen from the G2 Luyashan Tunnel exit to the G3 starting point, the line is continuous downhill. After entering the G3 segment, the route is downhill to Kelan County, and uphill to Ganqin Mountain Tunnel. Then continue to decline into the G4 segment, the overall trend of the longitudinal slope is slightly steeper at both ends( 1 and 4 paragraphs), It's more gentle in the middle(2 and 3 paragraph).

First section is Luyashan tunnel exit to Huangdaochuan $(\mathrm{K} 88+800 \sim \mathrm{K} 100+830)$, Its short chain is $1249.607 \mathrm{~m}$, continuous downhill length is $13.3 \mathrm{~km}$, average longitudinal slope is $-2.4 \%$. Among them, from the G2 section of the Luyashan tunnel exit to the K95+050 section, the route length is $7.5 \mathrm{~km}$, average longitudinal slope is $-2.5 \%$. Referring to the rules, here is to meet the conditions set safe Lane, therefore, combined with the field topography, set a hedge lane at K94+170. The rest of the location does not have the conditions to set hedge lanes.

The second section is Huangdaochuan county to Kelan $(\mathrm{K} 100+830 \sim \mathrm{K} 114+600)$. Its line length is $13.8 \mathrm{~km}$, average longitudinal slope is $-1 \%$ (downhill). It does not belong to the category of long downhill, and does not need to set the hedge lane.

The third section is Kelan county to Ganqinshan tunnel $(\mathrm{K} 114+600 \sim \mathrm{K} 140+380)$. Its short chain is $276.911 \mathrm{~m}$, line length is $26.1 \mathrm{~km}$, average longitudinal slope is $0.82 \%$. The route is up and down, and the general trend is uphill, so it does not belong to the category of long downhill, and does not need to set the hedge lane.

The fourth is Ganqingshan tunnel to $\mathrm{G} 3$ section of the end $(\mathrm{K} 140+380 \sim \mathrm{K} 151+085)$. The line length is $10.7 \mathrm{~km}$, average longitudinal slope is $-2.43 \%$. At the K140+380 K147+880 segment, the route length is $7.5 \mathrm{~km}$, average longitudinal slope is $-2.57 \%$, therefore, combined with the field topography, set a hedge lane at K146+010. The rest of the location does not have the conditions to set hedge lanes.

\subsection{Restriction factor in the choice of hedge lane length}

The principle of Truck Escape Ramp setting is to convert the kinetic energy of the vehicle out of control into gravitational potential energy and the friction of the road surface. Therefore, the main factors influencing the length of safe haven are the speed of the vehicle and the material used in the lane slope bed. The materials with the big rolling resistance coefficient can effectively reduce the emergency lane length, save the cost, but also can make the vehicle suddenly encounter great 
resistance and the vehicle chassis quickly stop, at the same time, the cabin and cargo, easy for cab extrusion, thus causing casualties. Therefore, the selection of slope bed material of safe haven should be considered on safe, economical and other hands.

\subsection{Hedge Lane Design}

K94+170 hedge lane

The hedge lane set on the right side of the main line of the K94+170. the main line is a straight line, longitudinal slope is $-1.9 \%$. Hedge lane is a straight line, longitudinal slope is $19 \%$, the main line of the triangle gradual segment length is $80 \mathrm{~m}$, the angle is 18 degrees, slope bed length is $170 \mathrm{~m}$, lane width is $4.5 \mathrm{~m}$, service road width is $3.5 \mathrm{~m}$, total width of roadbed is $9.5 \mathrm{~m}$. The brake slope bed uses the bean gravel. Service road surface is the same as main line. at the end of brake slope bed set buffer facilities such as waste tires.

K146+010 hedge lane

The hedge lane set on the right side of the main line of the $\mathrm{K} 146+010$, the main line is a circle curve of $\mathrm{R}=887.312 \mathrm{~m}$, longitudinal slope is $-2.0 \%$. Hedge lane is a straight line, longitudinal slope is $20 \%$, the main line of the triangle gradual segment length is $80 \mathrm{~m}$, the angle is 10 degrees, slope bed length is $150 \mathrm{~m}$, lane width is $4.5 \mathrm{~m}$, service road width is $3.5 \mathrm{~m}$, total width of roadbed is $9.5 \mathrm{~m}$. The brake slope bed uses the bean gravel. Service road surface is the same as main line. At the end of brake slope bed set buffer facilities such as waste tires.

Because the impact of multiple factors in the two hedge lanes, such as terrain conditions and engineering cost, the selection index of safe slope is low. in the future design, if the conditions allow, we should give priority to the selection of high indicators of the longitudinal slope.

\section{Design experience}

As a powerful measure to reduce the vehicle out of control accident, hedge lanes should be fully valued. in the design and management should pay full attention to the following points:

1.To strengthen the control of the overload vehicles, let the hidden dangers in the bud.

2.Improve service facilities, set up vehicle inspection area, cooling pool in the right place, and improve the traffic sign.

3. Slope bed material of hedge lane should be chosen reasonably. We use non graded materials which have high rolling resistance coefficient, not easy to harden, not easy to be washed. And to turn it on a regular basis, we improve the drainage system of hedge, to ensure that the material can have the normal rolling resistance coefficient to complete the braking of the vehicle.

4.According to the different average longitudinal slope in the "design rules of highway route "(main version)" and the route to increase the length of additional hedge Lane, we should recommend to make full technical and economic comparison before the decision.

\section{References}

[1] JTG D20-2006, 《Code for design of highway route》[S].BeiJing:China Communications Press, 1999

[2] JTG B01-2003, 《Technical standard of Highway Engineering 》 [S].BeiJing:China Communications Press, 2003

[3] JTG /T D20-200X , "Highway route design rules》 (Total release)

[4] Xu Hui-fen, BM Tang, Xu Jian-tao. Analysis on long and steep downhill road safety [J].Journal of Chongqing Jiaotong University, 2007:1-3.

[5] G Liang, G Qian, LI Rui, X Zhang, Z Chen.Speed Limit Value Based on Safety and Efficiency for Long and Steep Downhill of Expressway Under Traffic Incident[J].China Journal of Highway \& Transport, 2015:2-3. 
[6] Y Shi, Y Chen.Study on safety evaluation method in linear design of downhill road[J].Road Traffic \& Safety, 2009:2-3. 